\title{
Karakteristik Jaringan Secara Histologi dari Strain Rumput Laut (Kappaphycus alvarezii) yang Terinfeksi Penyakit Ice-Ice
}

\author{
Histological Tissue Features of Red Seaweed Strain \\ Kappaphycus alvarezii Infected by Ice-Ice Disease? \\ Resi Kumala Maulani ${ }^{1}$, Marlina Achmad ${ }^{1 凶}$, dan Gunarto latama ${ }^{1}$ \\ ${ }^{1}$ Program Studi Budidaya Perairan, Departemen Perikanan, FIKP, Universitas Hasanuddin \\ Jln. Perintis Kemerdekaan Km 10, Makassar, 9024 \\ ${ }^{凶}$ corresponding author: marlina.achmad@unhas.ac.id
}

\begin{abstract}
Abstrak
Salah satu yang menyebabkan kegagalan budidaya rumput laut Kappaphycus alvarezii yaitu terserangnya penyakit ice - ice. Penyakit ice-ice merupakan penyakit yang umum terjadi pada rumput laut kappaphycus dengan gejala terjadinya pemutihan pada bagian thallus dan penyakit ini dapat menyebabkan kematian massal pada produksi rumput laut kappaphycus alvarezii. Salah satu cara yang dapat dilakukan untuk menganalisa bagian thallus rumput laut Kappaphycus alvarezii yaitu uji histopatologi. Penelitian ini bertujuan untuk mengetahui perubahan bentuk sel pada kondisi jaringan thallus rumput laut K.alvarezii yang terserang penyakit ice-ice menggunakan metode histopatologi. Pengambilan sampel rumput laut yang digunakan jenis Kappaphycus alvarezii varietas coklat dan hijau dengan 1 titik masing - masing varietas. Sampel rumput laut terdiri atas 2 sampel yaitu bagian thallus yang terserang penyakit ice-ice dan bagian thallus tanpa gejala ice-ice. Sampel berumur 15 hari. Sampel yang dipilih untuk pemeriksaan, dipotong setebal 0,5 $-1 \mathrm{~cm}$. Sampel dimasukkan kedalam botol sampel untuk difiksasi \pm 1 minggu, yang berisi formalin 10\%.Tahapan pembuatan preparat histopatologi terdiri atas fiksaksi, dehidrasi, clearing, impregnasi, embedding, cutting, staining, dan pemeriksaan dibawah mikroskop. Penelitian ini dianalisis secara dekskriptif kualitatif dengan melakukan pengamatan gambar histopatologi pada jaringan rumput laut $K$. alvarezii. Jaringan thallus yang yang terserang penyakit ice-ice mengalami perubahan bentuk sel, bagian lapisan luar terlihat tidak utuh, hancur, sehingga mengalami kematian sel dan bagian korteks dalam dinding sel terlihat tidak teratur dan renggang, tidak terbentuk bulat atau lonjong, sebagian sel mengecil. Jaringan thallus yang tidak normal mengalami gejala Hipoplastik (terhambatnya atau terhentinya pertumbuhan sel) dan Nekrotik (kematian sel).
\end{abstract}

Kata kunci : Kappaphycus alvarezii, penyakit ice - ice, Histopatologi, Hipoplastik, Nekrotik

\begin{abstract}
The cause of the failure of seaweed cultivation Kappaphycus alvarezii is the ice-ice disease onset. Ice-ice is a common disease in Kappaphycus seaweed with bleaching symptoms in the thallus it can be generate the mass death in the production of kappaphycus alvarezii. The methods that conducted to analyze the of thallus is histopathology test. This study aims to determine the changes in the shape of cells in tissue thallus seaweed $K$. alvarezii that attacked by ice-ice disease using histopathology method. Seaweed sampling used Kappaphycus alvarezii strains both of brown and green with 1 point each varieties. Seaweed samples consist of 2 samples, the thallus parts suffered from ice-ice disease and thallus parts without symptoms of ice-ice. Sample is 15 days old. The samples were selected for examination, cut $0.5 \mathrm{~cm}-1 \mathrm{~cm}$ thick. The sample is inserted into the sample bottle for \pm 1 week fixation, containing $10 \%$ formalin. The stages of making of histopathologic preparations consist of fixation, dehydration, clearing, impregnation, embedding, cutting, staining, and examination under a microscope. This study was analyzed qualitatively by sketching histopathologic images on seaweed $K$. alvarezii tissues. The thallus tissues that are affected by the ice-ice disease changes cell shape, the outer part of the outer layer looks incomplete, destroyed, and cortical part within the cell wall appear irregular and tenuous, not round or oval, some cells shrink. The abnormal thallus tissues are of having symptoms of Hypoplastic (inhibition or cessation of cell growth) and Necrotic (cell death).
\end{abstract}

Keywords: Kappaphycus alvarezii, ice-ice disease, histopathology, hipoplastic, necrotic. 


\section{Pendahuluan}

Rumput laut salah satu komoditas ekspor yang potensial untuk dikembangkan dan ditetapkan dalam program revitalisasi perikanan sejak tahun 2005 dalam peningkatan kesejahteraan masyarakat. Rumput laut merupakan makro alga laut sebagai sumber utama karaginan, alginat, dan agar yang bersifat multiguna dalam berbagai aspek kehidupan manusia (Nurdjana, 2006). Menurut Sujatmiko (2003), Jenis rumput laut yang mempunyai nilai ekonomis dan sudah banyak dibudidayakan secara intensif di wilayah pesisir adalah jenis K.alvarezii.

Rumput laut K.alvarezii di laut dikelompokan menjadi varietas coklat dan hijau. Menurut Parenrengi et al, (2006) varietas hijau mempunyai ketahanan dan pertumbuhan yang lebih baik dibandingkan varietas coklat pada musim kemarau sedangkan varietas coklat pada musim hujan. Salah satu faktor yang mempengaruhi Keberhasilan budidaya rumput laut K.alvarezii adalah kondisi perairan laut yang fluktuatif dan cenderung ekstrim seperti salinitas dibawah 20 ppt dan diatas kisaran optimal $30 \mathrm{ppt}$, suhu air diatas $35^{\circ} \mathrm{C}, \mathrm{pH}$ yang terlalu asam dan basa, tingkat kecerahan air diatas $5 \mathrm{~m}$ dan kekurangan nutrisi merupakan faktor utama pemicu berjangkitnya penyakit ice-ice.

Penyakit ice-ice merupakan penyakit yang umum terjadi pada rumput laut K.alvarezii dengan gejala terjadinya pemutihan pada bagian thallus dan penyakit ini dapat menyebabkan kematian massal pada produksi rumput laut K.alvarezii. Menurut Vairappan et al., (2008) menyatakan bahwa pengendalian penyakit ice-ice pada rumput laut K.alvarezii di Indonesia belum tertangani dengan baik yang berakibat penurunan produksi rumput laut berkisar 70$100 \%$.

Penyakit ice-ice menyebabkan bagian thallus memutih, mudah patah sehingga memperlambat pertumbuhan rumput laut K. alvarezii. Menurut Darmawati, (2014) menyatakan bahwa pertumbuhan thallus merupakan pertambahan ukuran sel atau perubahan dari sejumlah sel yang mempunyai struktur dan fungsi yang berbeda. Pola pertumbuhan rumput laut menyebabkan terjadinya penambahan jumlah massa sel penyusun thallus. Oleh Karena itu, menganalisa jaringan thallus rumput laut $K$. alvarezii dapat dilakukan uji histologi.

Histologi yaitu ilmu yang mempelajari tentang jaringan. Histopatologi adalah ilmu yang mempelajari kondisi dan fungsi jaringan dalam hubungannya dengan penyakit. Histopatologi berperan sangat penting dengan diagnosis penyakit karena salah satu pertimbangan dalam penegakan diagnosis melalui hasil pengamatan terhadap jaringan yang diduga terganggu (Rizki et al., 2015). Uji histopatologi dapat mengetahui perubahan sel pada thallus rumput laut $K$. 
alvarezii yang terinfeksi penyakit ice-ice. Dengan demikian, perlu dilakukan penelitian tentang histopatologi rumput laut $K$. alvarezii varietas coklat dan hijau untuk untuk melihat kerusakan jaringan thallus rumput laut K.alvarezii yang terserang penyakit ice-ice.

\section{Bahan dan Metode}

\section{Pengumpulan sampel}

Sampel rumput laut untuk penelitian ini berasal dari perairan Punaga di Desa Punaga, Kecamatan Mangarabombang, Takalar. Lokasi pengambilan sampel disajikan pada Gambar 1. Selanjutnya, sampel yang akan digunakan untuk preparat histologi dibawa ke Laboratorium Patologi Klinik, Balai Besar Veteriner Maros, dan akan dianalisa di Laboratorium Parasit dan Penyakit Ikan, Departemen Perikanan, Fakultas Ilmu Kelautan dan Perikanan, Universitas Hasanuddin.
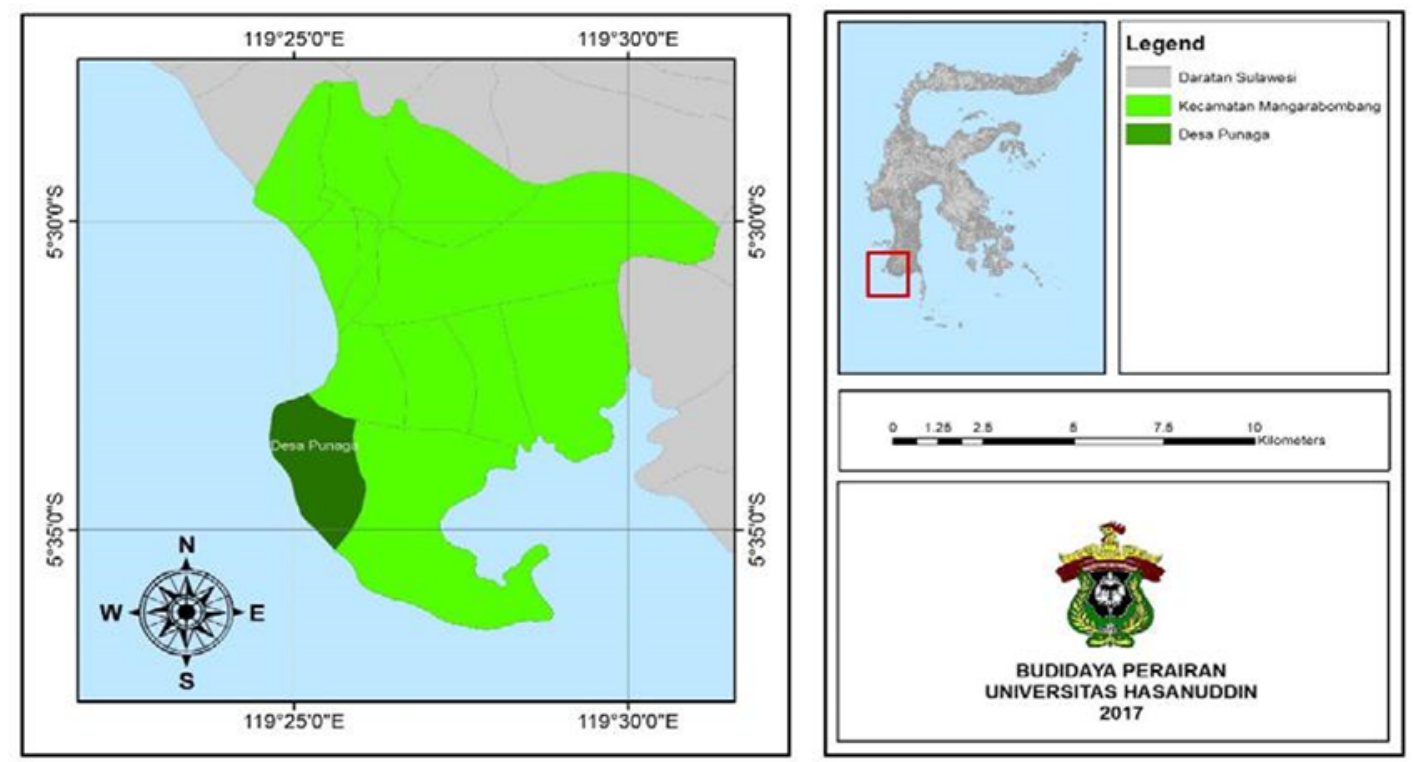

Gambar 1. Lokasi pengambilan sampel rumput laut Kappaphycus alvarezii, di desa Punaga, Kecamatan Mangarabombang, Kabupaten Takalar.

\section{Persiapan material}

Pengambilan sampel rumput laut yang digunakan jenis $K$. alvarezii varietas coklat dan hijau dengan 1 transek terdapat 2 bentangan. Sampel rumput laut terdiri atas 2 sampel yaitu bagian thallus yang terserang penyakit ice-ice dan bagian thallus tanpa gejala ice-ice. Sampel yang dipilih untuk pemeriksaan, dipotong setebal $0,5-1 \mathrm{~cm}$. Pemotongan thallus yang terserang ice-ice, dilakukan dengan cara memotong diantara yang terserang dan tidak terserang, agar thallus yang terserang ice-ice tidak mudah patah dan hancur. Sampel dimasukkan ke dalam 
botol sampel yang berisi formalin $10 \%$, proses fiksasi di dalam botol dilakukan langsung pada saat pengambilan sampel.

\section{Analisis Histopatologi}

Tahapan kerja pembuatan preparat histopatologi dilakukan menurut modifikasi Andini (2015). Pertama, fiksasi, bertujuan untuk mempertahankan susunan jaringan agar mendekati kondisi seperti sewaktu hidup dan untuk mengeraskan jaringan terutama jaringan lunak agar memudahkan pembuatan irisan tipis. Sampel untuk pemeriksaan histopatologi dimasukkan kedalam larutan fiksasi yaitu Formalin 10\% dan disimpan terlebih dahulu beberapa hari sebelum dilakukan pemotongan untuk dilanjutkan ke pengujian histopatologi. Pada umumnya waktu yang diperlukan unutk fiksasi sempurna adalah 48 jam, setelah disimpan 2 hari didalam larutan fiksasi dilakukan pemotongan spesimen. Potongan spesimen dimasukkan kembali kedalam larutan fiksasi Formalin 10\% sebanyak 2 kali masing - masing 2 jam.

Selanjutnya, dehidrasi yang bertujuan untuk mengeluarkan air dari dalam jaringan dengan menggunakan alkohol bertingkat dalam waktu tertentu. Dehidrasi dengan alkohol 70\%, $90 \%, 100 \%$, 100\%, dan 100\%. Dehidrasi alkohol 70\%, 90\%, 100\% (alkohol bertingkat 100\% pertama) selama 1 jam dan alkohol 100\% (kedua dan ketiga) selama 2 jam. Kemudian, tahapan clearing yang bertujuan menarik sisa alkohol dari jaringan dan diganti dengan larutan yang dapat berikatan dengan paraffin. Tahapan clearing (penjernihan) dimulai dari perendaman dengan toluen I selama 1 jam, toluen II dan toluen III selama 1,5 jam.

Tahap impregnasi bertujuan untuk mengeluarkan cairan toluene (celaring agent) dari dalam jaringan dan diganti dengan paraffin. Impregnasi dilakukan dengan memasukkan spesimen kedalam paraffin cair sebanyak 2 kali masing - masing 2 jam dan 3 jam. Kemudian dilanjutkan Embedding. Embedding cassette dikeluarkan dari tissue processor dan masukkan ke dalam wadah yang telah tersedia pada alat embedding center. Keluarkan sampel dari keranjang tissue untuk di blok oleh paraffin satu-persatu (agar tidak tertukar). Tempatkan cetakkan dan keranjang pada sisi kanan dan kiri dispenser paraffin. Sampel diletakkan diatas cetakkan lalu diisi dengan paraffin dengan menekan tombol hitam yang telah tersedia pada alat embedding center. Cetakkan diberi nomer sesuai nomor sampel yang letakkan diatas keranjang yang berisi sampel. Pindahkan cetakan pada bagian dingin. Setelah beku (mengeras paraffinnnya) pisahkan cetakan dengan keranjang, setelah terpisah pindahkan keranjang, siap untuk dilakukan pemotongan dengan mikrotom knife.

Selanjutnya, tahap Pemotongan)Mengambil blok jaringan kemudian difiksir pada microtome. Blok jaringan dipotong dengan microtome kasar sehingga didapatkan permukaan 
yang rata. Menggunakan pisau mikrotom yang masih tajam, ketebalan potongan 5-6 mikron. Pilih potongan jaringan terbaik dari pita yang terbentuk. Potongan yang terpilih direntangkan pada floating out yang bersuhu sekitar 400C yang terlebih. Suhu yang ideal akan mengakibatkan potongan jaringan merentang sempurna, tidak berkerut. Menaburkan gelatin powder sebanyak 5 gram untuk $100 \mathrm{cc}$ aquadest dan biarkan larut sempurna. Potongan yang bagus, tidak tergores, tidak mengkerut dipilih dan diambil dengan gelas slide yang sudah bernomer sesuai dengan nomer epi/patologi. Slide yang berisi tempelan potongan jaringan ditempatkan diatas pelat pemanas slide, minimal dua jam.

Terakhir adalah tahapa pewarnaan (staining) dan pemeriksaan mikroskopik. Semua bahan pewarna harus diperiksa kejernihannya dan disesuaikan dengan jadwal penggantian yang tersedia (3 kali penggunaan setiap pemakaian). Pewarna yang digunakan adalah Hematoxylin dan eosin, Setelah selesai pewarnaan dilakukan coverslipping, siapkan coverslip secukupnya sesuai dengan jumlah preparat yang baru saja diwarnai lalu teteskan 1-2 tetes "entellan" pada tiap coverslip. Balik dan tutupkan pada slide preparat yang baru saja diwarnai, cegah jangan sampai terbentuk gelembung udara, biarkan preparat yang sudah tertutup dengan coverslip lalu dibiarkan sampai mengering sempurna. Bersihkan slide glass dengan xylol lalu berilah nomor sesuai dengan nomor yang ada dietiket slide glass tersebut.

\section{Pengukuran Kualitas Air}

Pengukuran kualitas air di lapangan yakni suhu, salinitas, kecerahan, nitrat, dan fosfat. Suhu diukur menggunakan thermometer, salinitas menggunakan handrefractometer. Selanjutnya pengukuran nitrat dan fosfat ddilakukan di Laboratorium Kualitas Air, Fakultas Ilmu Kelautan dan Perikanan Unhas.

\section{Analisis Data}

Data gambaran jaringan rumput laut dianalisis secara dekskriptif kualitatif dengan melakukan pengamatan histopatologi pada jaringan rumput laut $K$. alvarezii.

\section{Hasil dan Pembahasan}

\section{Kondisi jaringan thallus rumput laut $K$. alvarezii varietas coklat dan hijau yang tidak terserang dan terserang penyakit ice-ice}

Rumput laut $K$. alvarezii yang tidak terserang penyakit ice-ice dan terserang penyakit iceice juga memiliki perbedaan pada kondisi jaringan, untuk melihat kondisi jaringan rumput laut 
yang sehat dan yang terserang ice-ice terlebih dahulu membuat preparat histologi. Kondisi penampang jaringan rumput laut K.alvarezii varietas coklat yang sehat dan terserang ice-ice dapat dilihat pada Gambar 2.
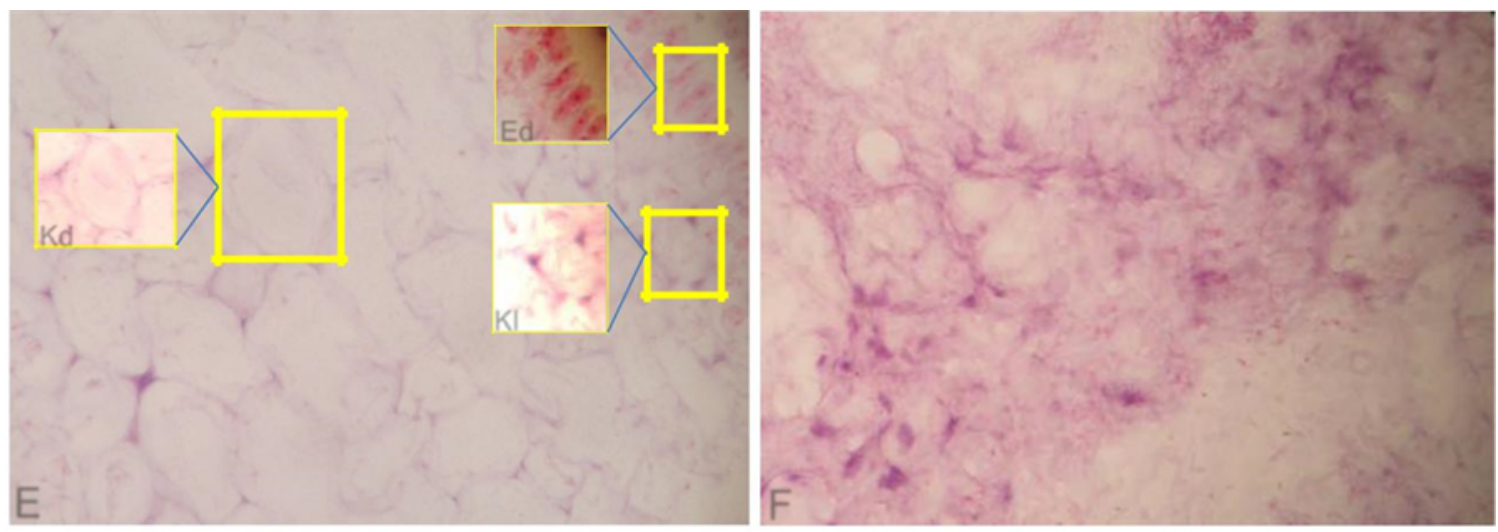

Gambar 2. Jaringan thallus varietas coklat irisan melintang. Jaringan sehat (E), terserang ice-ice (F). Epidermis (ed), korteks luar (kl), korteks dalam (kd). Pembesaran 400x. Pewarnaan H\&

Kondisi penampang jaringan thallus rumput laut K.alvarezii varietas coklat, gambar (E) merupakan jaringan sehat rumput laut K.alvarezii varietas coklat, $(F)$ jaringan yang terserang penyakit ice-ice. Jaringan sehat komponen penyusun sel terlihat jelas antara epidermis, korteks luar, korteks dalam. Jaringan yang terserang ice-ice komponen penyusun sel sudah terlihat tidak jelas, hancur, mengalami kerusakkan. Kondisi penampang jaringan thallus rumput laut K.alvarezii varietas hijau yang sehat dan terserang penyakit ice-ice dapat dilihat pada Gambar 3 .
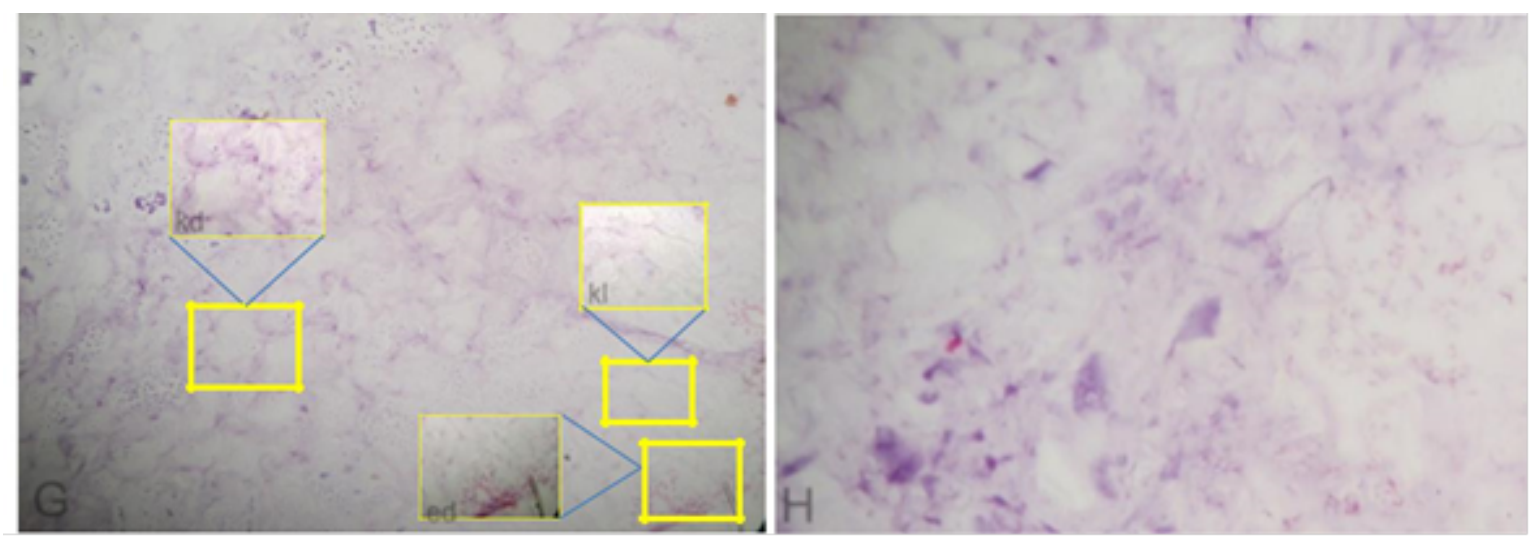

Gambar 3. Jaringan thallus varietas hjau irisan melintang. Jaringan sehat $(\mathrm{G})$, terserang penyakit ice-ice $(\mathrm{H})$. Epidermis (ed), korteks luar (kl), korteks dalam (kd). Pembesaran 400x. Pewarnaan

Kondisi penampang jaringan thallus Rumput Laut K.alvarezii varietas hijau, gambar (G) merupakan kondisi jaringan sehat rumput laut K.alvarezii varietas hijau, $(\mathrm{H})$ jaringan yang terserang ice-ice. Gambar 9.G Jaringan sehat komponen penyusun sel terlihat jelas antara 
epidermis, korteks luar, korteks dalam. Gambar 9.H Jaringan yang terserang ice-ice komponen penyusun sel terlihat tidak jelas, hancur, mengalami kerusakan, tetapi masih terlihat sel berbentuk bulat kecil dan agak persegi panjang di daerah epidermis yang sudah tidak beraturan dan mulai renggang. Kerusakan jaringan akibat infeksi penyakit ice-ice menyebabkan sel rumput laut mengalami perubahan bentuk sel.

Indikator pemisahan ketiga kondisi jaringan dilihat berdasarkan sel epitelia, jumlah protoplasma dan jarak antar sel. Jaringan yang terserang penyakit ice-ice, nampak sel-sel epitel tereduksi, kandungan protolasma sel berkurang. Pada kondisi sehat bentuk sel yaitu jarak sel nampak masih rapat. Kondisi jaringan thallus tidak parah yaitu jarak sel mulai renggang dan kondisi sangat parah yaitu jarak antar sel sangat renggang. Sehingga Gambar 2.F digolongkan sangat parah yaitu komponen penyusun sel tidak jelas, hancur. Gambar 3.H digolongkan tidak parah yaitu komponen penyusun sel tidak jelas, tetapi masih terlihat sel berbentuk bulat kecil dan agak persegi panjang di daerah epidermis yang sudah tidak beraturan dan mulai renggang (Achmad 2016). Selanjutnya, hasil penelitian Quere et al., (2015) menyimpulkan bahwa pada jaringan yang sangat parah, hanya sel-sel epitel bagian luar yang telah menunjukkan kemerosotan dan jaringan mati ditandai dengan sel-sel epitel mulai hilang atau terlihat tidak padat.

Infeksi penyakit ice - ice pada thallus rumput laut K.alvarezii selain dapat merusak bagian epidermis, dapat juga merusak lapisan pseduoparenkim yaitu korteks luar dan korteks dalam. Perubahan sel yang terjadi bagian korteks dalam yaitu jarak antara sel (dinding sel). Jaringan rumput laut K.alvarezii varietas coklat bagian korteks dalam dapat dilihat pada Gambar 4. Hal tersebut sesuai dengan pernyataan Quere et al., (2015) Pada jaringan yang terserang penyakit, menunjukkan sel-sel dengan dinding sel utuh, tetapi berkurang kandungan sitoplasmik yang ditandai dengan perubahan intensitas pewarnan.

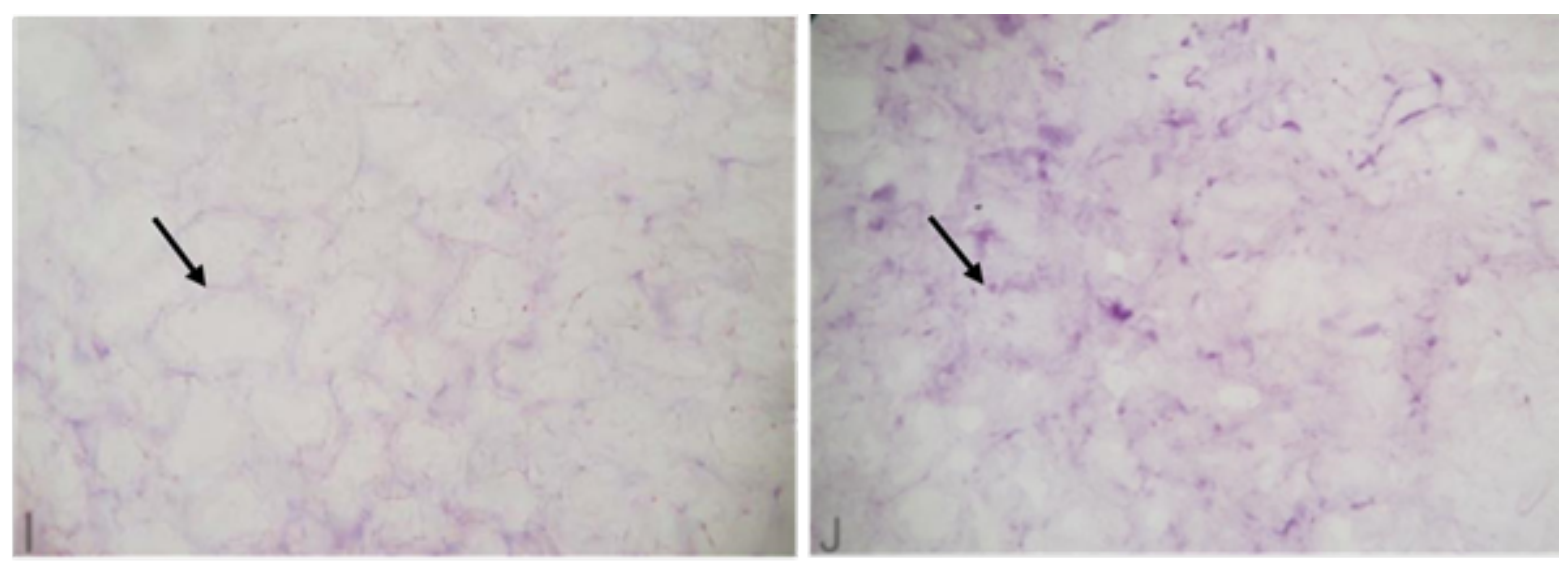

Gambar 4. Jaringan Rumput laut K. alvarezii varietas coklat bagian korteks dalam. Jaringan sehat (I), terserang ice-ice (J). Pembesaran 400x. Pewarnaan H\&E, dinding sel (panah hitam) 
Jaringan rumput laut K.alvarezii varietas coklat menunjukkan bagian kortek yang terlihat dengan bentuk sel yang sehat, teratur dan tidak renggang, antar dinding sel rapat. Sedangkan pada Gambar 4J menunjukkan serangan ice-ice yang ditandai dengan dinding sel yang tidak teratur, jarak antar sel sangat renggang. Kondisi jaringan thallus varietas cokelat bagian korteks dalam disajikan pada Gambar 5.
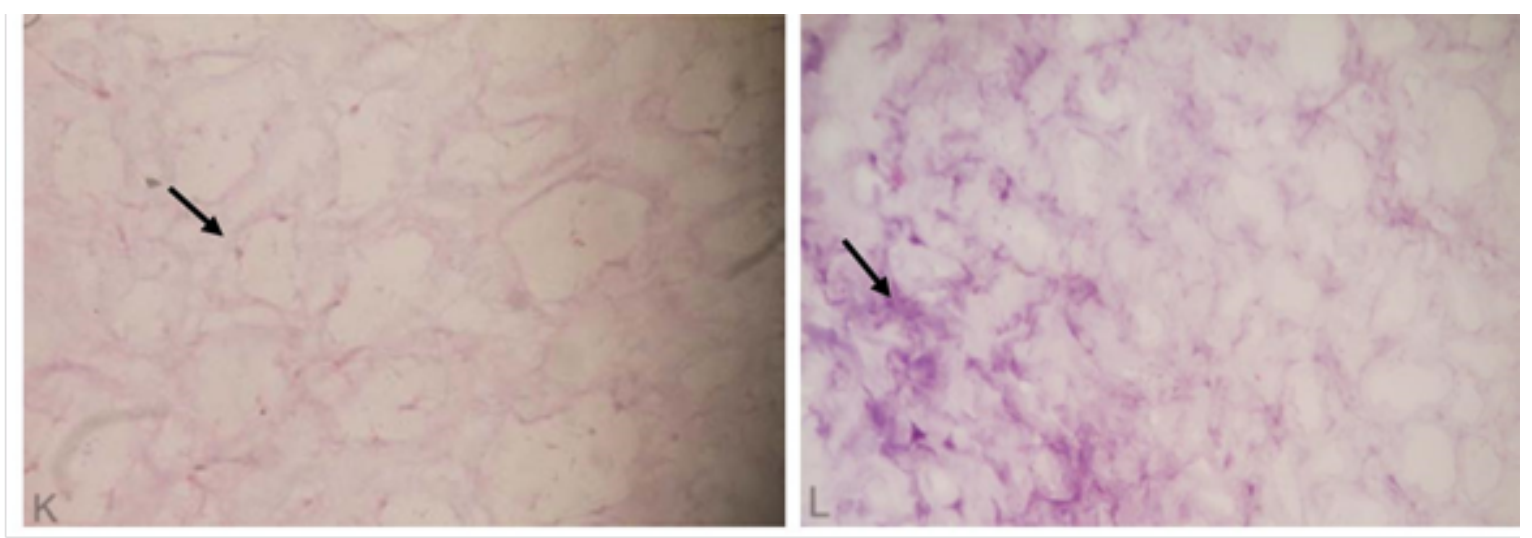

Gambar 5. Jaringan Rumput laut K. alvarezii varietas hijau bagian korteks dalam. Jaringan sehat (K), terserang ice-ice (L). Pembesaran 400x, pewarnaan H\&E, dinding sel (panah hitam

Kondisi jaringan Rumput Laut K.alvarezii Varietas Hijau bagian korteks dalam. Gambar 5.K merupakan bentuk sel yang sehat, teratur dan tidak renggang, antara dinding sel rapat dan 5.L terserang ice-ice. Gambar 5.L terlihat jarak antara sel mulai renggang tetapi masih terlihat sel yang masih normal belum keseluruhan sel yang telah rusak. Bentuk sel normal dan tidak normal rumput laut K.alvarezii memiliki perbedaan. Berdasarkan keterangan tersebut terjadinya kerusakan dinding sel yang sehingga mengalami perubahan bentuk sel. Menurut Achmad (2016), jaringan yang terserang penyakit ice-ice dinding sel tidak utuh (perubahan warna hitam menjadi tidak jelas). Pada kondisi thallus normal bentuk sel yaitu jarak sel nampak masih rapat. Kondisi jaringan thallus tidak parah yaitu jarak sel mulai renggang dan kondisi sangat parah yaitu jarak antar sel sangat renggang, sehingga Gambar 4.J dapat digolongkan sangat parah yaitu dinding sel tidak teratur, jarak antara sel sangat renggang. Pada Gambar 5.L digolongkan tidak parah yaitu jarak antara sel mulai renggang tetapi masih terlihat sel yang masih normal belum keseluruhan sel yang telah rusak. Kondisi jaringan thallus yang terinfeksi penyakit ice-ice varietas coklat mengalami perubahan sel yang sangat parah sedangkan varietas hijau tidak parah.

Selanjutnya, Menurut Lobban dan Harisson (1994) dalam Arisandi 2011), Kerusakan yang parah disebabkan oleh penyakit menyebabkan dinding sel pecah, sehingga cairan sel keluar dan mengakibatkan bentuk sel menjadi tidak beraturan (Plasmolisis). Menurut Juwono 
dan Juniarto (2003), apabila dinding sel mengalami kerusakan maka mengakibatkan terjadinya perubahan bentuk sel. Sehingga hasil pengamatan secara mikroskopis dalam penelitian ini terbukti bahwa, terjadinya kerusakan dinding sel bagian korteks dalam mengakibatkan perubahan bentuk sel.

Gejala awal rumput laut $K$. alvarezii yang terinfeksi penyakit ice-ice ditandai dengan mulai berkerutnya dinding sel, sehingga ukuran sel menjadi lebih kecil dari ukuran semula (Arisandi, 2011). Menurut Lakitan (2011), bahwa dinding sel tanaman mempunyai fungsi utama sebagai pelindung dan rangka sel, sehingga dinding sel yang mengalami kerusakan atau terdegradasi maka dapat mengakibatkan terjadinya perubahan bentuk sel. Dinding sel mempunyai fungsi lain berperan penting dalam proses distribusi nutrient. Rusaknya dinding sel dapat mengganggu penyerapan nutrient ke dalam sel, sehingga metabolisme terganggu, enzim rusak dan menghambat pembelahan sel (Salisbury dan Ross, 1992 dalam Arisandi, 2011).

Kerusakan jaringan thallus rumput laut K.alvarezii yang terserang penyakit ice-ice dapat disesuaikan dengan tipe gejala penyakit yang disebabkan oleh adanya perubahan di dalam selsel bagian tanaman (Purnomo, 2006). Adapun gejala penyakit disajikan pada Tabel 1.

Tabel 1. Gejala penyakit tanaman

\begin{tabular}{|c|c|c|}
\hline Tingkatan & $\begin{aligned} \text { Tipe } & \text { Gejala } \\
\text { Penyakit } & \end{aligned}$ & Perubahan Sel \\
\hline 1 & Hipoplastik & $\begin{array}{llll}\text { Gejala yang disebabkan terhambatnya atau } \\
\text { terhentinya pertumbuhan sel }\end{array}$ \\
\hline 2 & Nekrotik & $\begin{array}{l}\text { Gejala yang disebabkan karena adanya kerusakan } \\
\text { pada sel atau kerusakan bagian sel atau matinya sel. }\end{array}$ \\
\hline
\end{tabular}

Gejala penyakit pada jaringan thallus yang terserang penyakit ice-ice. Kondisi Penampang jaringan thallus rumput laut $K$. alvarezii varietas coklat dan hijau yang terserang penyakit ice-ice terlihat komponen penyusun sel tidak jelas, susunan sel tidak rapat, hancur dan dikatakan kerusakan yang parah dan mengalami kematian sel sehingga dari keterangan kondisi tersebut diduga gejala nekrotik. Kondisi jaringan thallus bagian korteks dalam yang tidak normal terlihat tidak teratur, renggang, tidak terbentuk bulat atau lonjong, terlihat bentuk sel mengecil daripada keadaan normal. Dinding sel menjadi kecil dari ukuran normal dikatakan terhambat atau terhentinya pertumbuhan sel, dari keterangan kondisi tersebut mengalami gejala Hipoplastik (terhambatnya atau terhentinya pertumbuhan sel).

Hasil yang didapatkan jaringan thallus rumput laut K.alvarezii varietas coklat dan hijau yang terserang penyakit ice-ice di duga mengalami gejala Hipoplastik dan Nekrotik, penelitian 
sebelumnya belum ada yang mengindikasikan bahwa thallus jaringan rumput laut K.alvarezii yang terserang penyakit ice-ice mengalami gejala Hipoplastik dan Nekrotik. Sesuai dengan pernyataan dan penelitian Dunn et al., (2002); Franklin et al. (2006) dalam Achmad (2016), menyatakan bahwa histologi dapat mengkonfirmasi kematian sel, namun tidak dapat menentukan apakah kematian sel merupakan hasil nekrosis atau programmed cell death (PCD. Fenomena ini jarang diteliti pada alga multiseluler dan sedikit permahaman terkait fenomena tersebut. Nekrosis dicirikan dengan vakuolisasi, sel pecah, degradasi jaringan dan PCD dicirikan dengan pengurangan sel, formasi dari akumulasi tubuh.

\section{Kesimpulan}

Hasil penelitian ini menyimpulkan bahwa jaringan thallus rumput laut K.alvarezii yang terserang penyakit ice-ice mengalami perubahan bentuk sel, komponen penyusun sel sudah terlihat tidak jelas, hancur sehingga mengalami kematian sel dan bagian korteks dalam dinding sel terlihat tidak teratur, renggang, tidak terbentuk bulat atau lonjong dan terlihat bentuk sel mengecil daripada keadaan normal. Selanjutnya, jaringan thallus yang terserang penyakit iceice mengalami gejala Hipoplastik (terhambatnya atau terhentinya pertumbuhan sel) dan Nekrotik (kematian sel).

\section{Daftar Pustaka}

Achmad, M. 2016. Studi Peran Interaksi Bakteri Patogen Dan Lingkungan Terhadap Penyakit Ice-ice Pada Rumput Laut Kappaphycus alvarezii. Sekolah pascasarjana. Institut Pertanian Bogor. Bogor.

Akmal, Raharjo S. Ilham. 2010. Teknologi Manajemen Budidaya Rumput Laut (Kappaphycus alvarezii). Makalah. Departemen Kelautan dan Perikanan. Direktorat Jenderal Perikanan Budidaya. Balai Budidaya Air Payau. Takalar. 22 hlm.

Amiluddin, N.M. 2007. Kajian Pertumbuhan dan Kandungan Karaginan Rumput Laut Kappaphycus alvarezii yang Terkena Penyaki Ice Ice di Perairan Pulau Pari Kepulauan Seribu. Institute Pertanian Bogor. Bogor.

Anggadiredja, T.J, Ahmad, Z., Heri, P., Sri, I. 2007. Rumput Laut.Penebar swadaya. Jakarta.

Anggadiredja J, Purwoto A, Istini S. 2011. Seri Agribisnis Rumput Laut. Penebar Swadaya. Jakarta.

Andini, N, S. 2015. Gambaran Histopatologi Insang, Hepatopankreas, dan Ginjal Ikan Butini (Glossogobius matanensis, Weber) di Danau Matano Sulawesi Selatan Yang Tercemar Logam Berat Nikel (Ni) Dan Besi (Fe). Skripsi. Program Studi Kedokteran Hewan. Fakultas Kedokteran. Universitas Hasanuddin. Makassar

Aris, M. 2011. Identifikasi, patogenisitas bakteri dan pemanfaatan gen 16S-rRNA untuk deteksi penyakit ice-ice pada budidaya rumput laut Kappaphycus alvarezii. Sekolah pascasarjana. Institut Pertanian Bogor. Bogor 
Arisandi, A., Akhmad, F. 2014. Dampak Faktor Ekologis Terhadap Sebaran Penyakit Ice-ice. Jurnal Kelautan. Program Studi Ilmu Kelautan. Universitas Trunojoyo. Madura. 7(1): 1907-9931

Arisandi, A., Marsoedil., Happy, N., Aida, S. 2011. Pengembangan Kultur Jaringan Untuk Menghasilkan Bibit Rumput Laut. Fakutas Pertanian Universitas Trunojoyo.

Darmawati. 2014. Analisa Histologi Sel Euchema cottoni Pada Kedalaman Berbeda. Jurnal Ilmu Perikanan. Program Studi Budidaya Perairan, Fakultas Pertanian, Universitas Muhammadiyah Makassar. Vol 3(1): 269-274

Daniel B.A. 2012. Produktivitas Rumput Laut Kapaphycus alvarezii Yang di Budidayakan Oleh Masyarakat Pesisir. Jurusan Perikanan dan Kelautan Fakultas Pertanian Universitas Nusa Cendana. Kupang

Destalino, 2013. Cara Mudah Budidaya Rumput Laut Menyehatkan dan Menguntungkan. Kansius. Yogyakarta.

Djokosetiyanto, D., I. Effendi, K.I. Antara. 2008. Pertumbuhan Kappaphycus alvarezii Varitas Maumere, Varitas Sacol dan Eucheuma denticulatum di Perairan Musi, Buleleng. Ilmu Kelautan, 13 (3): 171-176

DKP. 2004. Profil Rumput Laut Indonesia. Direktorat Jendral Perikanan Budidaya.Jakarta

Ditjenkan Budidaya, 2005. Profil Rumput Laut Indonesia. Direktorat Perikanan Budidaya, Departemen Kelautan dan Perikanan. Jakarta

Effendi, H. 2003. Telaah Kualitas Air. Kanisius. Yogyakarta

Franklin DJ, Brussaard CPD, Berges JA. 2006. What is the role and nature of programmedcell death in phytoplankton ecology? European Journal of Phycology. 41:1-14

Khasanah, U. 2013. Analisis Kesesuaian Untuk Lokasi Budidaya Rumput Laut Eucheuma cottonii Di Perairan Kecamatan Sajoanging Kabupaten Wajo. Skripsi. Jurusan Ilmu Kelautan. Fakultas Ilmu Kelautan dan Perikanan. Universitas Hasanuddin. Makassar

Lakitan, B. 2011. Dasar-dasar Fisiologi Tumbuhan. PT. Raja Grafindo Persada.Jakarta. 205 Hal.

Largo D.B, Fukami K, Adachi M, Nishijima T. 2003. Immunofluorescent detection of ice-ice Disease-Promoting Bacterial Strain Vibrio sp. P11 of the Farmed Macro Alga, Kappaphycus alvarezii of Aquatic Environmental Science (LAQUES). Departement of Aquaculture. Faculty of Agriculture. KochiUniversity-Japan.

Musa, N., Lee, S.W. 2008. Bacteria Attached on Cultured Seaweed Gracilaria changii at Mangabang Telipot, Terengganu. Academic Journal of Plant Sciences, 1(1): 01-04.

Nurdjana, M.L. 2006. Pengembangan budidaya rumput laut di Indoesia, dalam Diseminasi Teknologi dan Temu Bisnis Rumput Laut, Makassar 11 September 2006.Badan Riset Kelautan dan Perikanan. Departemen Kelautan dan Perikanan. Hal 1 - 35.

Rizki, M., Tia, R.S.M., Bastian, D. 2015. Uji Histopatologi Organ Ren, Insang, Ginjal, Intestinum dan Hepar Ikan Mas (Cyprinus carpio). Fakultas Perikanan dan Ilmu Kelautan. Universitas Padjadjaran. Bandung

Salmin. 2005. Oksigen Terlarut (DO) dan Kebutuhan Oksigen Biologi (BOD) Sebagai Salah Satu Indikator Untuk Menentukan Kualitas Perairan. Pusat Penelitian Oseanografi-LIPI, Jakarta. Vol 30 (3): 21 - 26 
Santoso, L., Yudha, T.N. 2008. Pengendalian Penyakit Ice-ice Untuk Meningkatkan Produksi Rumput Laut Indonesia. Jurnal Saintek Perikanan. Jurusan Budidaya Perairan, Fakultas Pertanian,Universitas Lampung

Sutrian, Y. 2004. Pengantar Anatomi Tumbuh-Tumbuhan (tentang sel dan jaringan). Rineka Cipta. Jakarta

Sujatmiko, W., Angkasa, W.I. 2003. Teknik Budidaya Rumput Laut Dengan Metode Tali Panjang. Pengkajian Ilmu Kehidupan-BPPT. Jakarta.

Sulistijo. 2002. Penelitian Budidaya Rumput Laut (Algae Makro/Seaweed) di Indonesia. Pidato Pengukuhan Ahli Peneliti Utama Bidang Akuakultur Pusat Penelitian Oseanografi Lembaga Ilmu Pengetahuan Indonesia.

Syamsuddin, R., Syamsu, A.R. 2014. Penanggulangan penyakit ice-ice pada rumput laut Kappaphycus alvarezii melalui penggunaan pupuk N, P, dan K. Simposium Nasional I Kelautan dan Perikanan. Makassar

Parenrengi, A., Sulaeman, E. Suryati, Lentulo, A. 2004. Variasi genetika rumput laut Kappaphcus alvarezii yang dibudidayakan di Sulawesi selatan.

Quer'e, G., Meistertzheim AL., Steneck RS., Nugues MN. 2015. Histopathology of crustose coralline algae affected by white band and white patch diseases. Peer J.1034:1-18

Yuniati, E. 2011. Karakteristik Fisiko-Kimia Karagenan dan Histologi Rumput Laut Kappaphycus alvarezii Dari Daerah Asal Bibit dan Umur Panen Berbeda. Sekolah pascasarjana. Institut Pertanian Bogor. Bogor

Yulianto K. 2002. Pengamatan Penyakit Ice-ice dan Alga Kompetitor Fenomena Penyebab Kegagalan Panen Budidaya Rumput Laut (Kappaphycus alvarezii) di Pulau Pari, Kepulauan Seribu. Prosiding Seminar Riptek Kelautan Nasional. Pusat Penelitian Oceanografi-LIPI. Jakarta.

Vairappan, C.S., Chung, C.S., Hurtado, A.Q., Soya, F.E., Bleicher-Lhonneur, G. Critchley, A. 2008. Distribution and symptoms of epiphyte infection in majorcarrageenophyteproducing farms. J. Appl. Phycol. 20: 477-48

Vairappan, C.S., Anang, S.P., Tan, K.T., Matsunaga, S. 2010. Role of Secondary Metabolites as Defense Chemicals Against Ice-ice Disease in Biofouler at Carrageenophyte Farms.

Zatnika, A. 2009. Pedoman Teknis Budidaya Rumput Laut. Badan Pengkajian dan Penerapan Teknologi, Jakarta653-660. 